\title{
In Vitro Evaluation of Fungicides and Plant Extract against Alternaria solani (Ellis) Causing Early Blight in Tomato (Lycopersicon esculentum Mill.)
}

\author{
Pankaj Kumar and S. Singh*
}

S.K. College of Agriculture and Research Station IGKV), Kawardha (Dist. Kabirdham)-491995, Chhattisgarh, India

*Corresponding author

\section{A B S T R A C T}

\begin{tabular}{l} 
Key w o r d s \\
$\begin{array}{l}\text { Alternaria solani, } \\
\text { Concentrations, } \\
\text { Fungicides, In vitro, } \\
\text { Plant extracts. }\end{array}$ \\
Article Info \\
$\begin{array}{l}\text { Accepted: } \\
\text { 14 July } 2017 \\
\text { Available Online: } \\
\text { 10 September } 2017\end{array}$ \\
\hline
\end{tabular}

Early blight disease of tomato caused by Alternaria solani (Ellis) is an economically important disease causing huge losses throughout Country. In the present investigation six fungicides viz. Trifloxystrobin 25\% w/w + Tebuconazole 50\%WG, Difenconazole 25\% EC, Hexaconazole $5 \%$ SC, Propineb $70 \mathrm{WP}$, Azoxystrobin 23\%SC, Thiafluzamide $24 \% \mathrm{SC}$ at 50,100, 250, 500 and $1000 \mathrm{ppm}$ concentration and Six plants extracts viz. Datura stramonium (Dhatura) green fruit extract, Azadirachta indica (Neem) seed kernel extract, Allium sativum (Garlic) bulb extract, Eucalyptus spp. (Eucalyptus) dry leaf extract, Crotalaria juncea (Sunhemp) seed extract, Euphorbia hirta (Bara Dudhi) whole plant extract at 1, 2, 3, 4 and 5 percent concentration were tested against A. solani under laboratory condition. Among the six fungicides, most effective fungicides was found Hexaconazole 5\% EC which exhibited 100.00 percent inhibition in mycelium growth at $100 \mathrm{ppm}$ followed by followed by Thiafluzamide $24 \%$ SC and Trifloxystrobin $25 \% \mathrm{w} / \mathrm{w}+$ Tebuconazole 50\% WG at 500ppm. Out of six plant extracts tested against A. solani in vitro, most effective plant extract was found Allium sativum @ 5\% which exhibited maximum inhibition in mycelium growth (45.15\%) followed by Crotalaria juncea @ 5\% $(44.40 \%)$, while minimum inhibition in mycelium growth was recorded in Euphorbia hirta.

\section{Introduction}

Tomato (Lycopersicon esculentum Mill.) is one of the most remunerative and widely grown vegetables in the world. It is a small annual or short lived perennial herb belonging to the family Solanaceae, probably native of 'Peru-Equador'. It is a regular kitchen component of Indian diet which is used as raw fruit and also as cooked processed products like soup, ketchup, sauce, pickle, pastes and powder. The pulp and juice of tomato is very digestible, promoter of gastric secretion and blood purifier, additionally it nutrients and metabolites (Folate, potassium, and vitamins $\mathrm{A}$ and $\mathrm{C}$ ) that are important for human health. Tomato is being extensively grown as an annual plant all over the world. Tomato has ranks second next to potato in world acreage but it has rank first among processing crops. It is cultivated in an area of 4.73 million hectares all over the world with production of 163.96 million tones and an average yield of 34.66 tones $\mathrm{ha}^{-1}$. In India, it is grown in a wide range of climate across states of Andhra Pradesh, Odisha, Karnataka, 
Maharashtra, West Bengal, Bihar, Gujarat, Uttar Pradesh, Madhya Pradesh and Chhattisgarh, accounting total production of 18732 thousand tones from an area of 774 thousand hectares with an average productivity of 24.20 tones ha $^{-1}$ during 2015 16 (Anonymous, 2016).

Tomato is highly sensitive to abiotic stresses especially extreme temperature, salinity, drought, excessive moisture and environmental pollution and biotic stresses. Tomato plants are suffered with large number of biotic stresses including insect pests and diseases from the time of emergence to harvest. More than 200 diseases have been reported to infect tomato in the world (Atherton and Rudich, 1986). Large number of fungal diseases such as early blight (Alternaria solani), Late blight (Phytophthora infestans), Septoria leaf blight (Septoria lycopersici), Powdery mildew (Oidiopsis taurica), Fusarium wilt (Fusarium oxysporum f. sp. lycopersici), Collar rot (Sclerotium rolfsii), and Damping off (Pythium sp.) are causes severe losses in tomato. Among the fungal diseases, early blight caused by Alternaria solani is one of the most important and frequent occurring disease of the crop nation and worldwide (Jones et al., 1991).

The early blight was the most catastrophic diseases incurring loss under field and postharvest stages causing 50 to 86 percent reduction in fruit yield (Mathur and Shekhawat, 1986). Saha and Das (2012) reported losses in yield 0.75 to 0.77 tons ha ${ }^{-1}$ with 1per cent increase in disease severity. Once early blight is established in the crop, it is very difficult to be controlled (Smith and Kotcon, 2002). Fungicide treatments are generally the most effective control measures, but are not economically feasible in all areas of the world and may not be effective under weather conditions favorable for disease epidemics. It is very essential to determine the efficacy of different fungicides and plant extracts against early blight of tomato. Therefore, keeping in view of above facts present experiments were conduct on "in vitro efficacy of fungicides against Alternaria solani causing early blight disease in Tomato (Lycopersicon esculentum Mill.)".

\section{Materials and Methods}

\section{Isolation, identification and purification of Alternaria solani}

Tomato leaves showing typical early blight symptoms were collected from growing tomato plants from different tomato growing fields during crop season. Standard tissue isolation technique was followed to obtain $A$. solani culture described by Naik et al., (2010). The leaves were microscopically examined to confirm the presence of the fungus. After confirming for the presence of fungal spores, isolation was done by following standard tissue isolation. The culture was purified by single spore technique described by Johnson and Booth (1983). In case of single spore technique 2 to 3 drops from spore suspension prepared from 10 days old culture with sterilized distilled water. Later $1 \mathrm{ml}$ of suspension was spread on the surface of plain agar medium in Petri plates and incubated at $25 \pm 2^{\circ} \mathrm{C}$ for $24 \mathrm{~h}$. The plates were observed for germinating spores under stereoscopic microscopic and finally germinating spores were lifted by inoculation needle and transferred aseptically to potato dextrose agar slants for further growth.

\section{Evaluation of fungicides}

The poisoned food technique (Nene and Thapliyal, 1993) was followed to evaluate the efficacy of six systemic fungicides viz. Trifloxystrobin 25\% w/w + Tebuconazole $50 \% \mathrm{WG}, \quad$ Difenconazole $25 \%$ EC, Hexaconazole $5 \%$ SC, Propineb 70 WP, Azoxystrobin $23 \%$ SC, Thiafluzamide $24 \%$ SC against $A$. solani at five concentrations (50, 
100, 250, 500 and 1000ppm). Fungicides were added to the potato dextrose agar medium before sterilization as per treatment detail. Five $\mathrm{mm}$ disc of $A$. solani was taken from seven days old culture and placed at center of petri dish. The activity of fungicides were recorded by measuring the colony diameter of $A$. solani in each treatment and compared with control.

\section{Evaluation of plant extracts}

Tested efficacy of plant extracts against Alternaria solani using poisoned food technique under in vitro conditions. Six plants extracts viz. Datura stramonium (Dhatura) green fruit extract, Azadirachta indica (Neem) seed kernel extract, Allium sativum (Garlic) bulb extract, Eucalyptus spp. (Eucalyptus) dry leaf extract, Crotalaria juncea (Sunhemp) seed extract, Euphorbia hirta (Bara Dudhi) whole plant extract were tested at 1, 2, 3, 4 and 5 percent concentration. Fresh healthy plant parts of $100 \mathrm{~g}$ (leaves/fruit/bulb) were collected from field, then they were washed with tap water, air dried and crushed in $100 \mathrm{ml}$ of sterile water. Potato dextrose agar medium was used as nutrient medium and required quantity of each plant extract was added separately to get a required concentration of the plant extract. The plant extract were thoroughly mixed with PDA medium and sterilized at $121^{\circ} \mathrm{C}$ for 20 minutes. Twenty milliliter of poisoned medium was poured to each of the $90 \mathrm{~mm}$ petri dishes and allowed for solidification.

Simultaneously without plant extract PDA was poured in petri dishes as control. Actively growing periphery of the 7 day old culture of A. solani was carefully cut using a cork borer and transferred aseptically to the centre of each petri dish containing the poisoned/nonpoison solid medium. The plates were incubated at $25 \pm 2^{\circ} \mathrm{C}$. Each treatment was replicated three times.

\section{Observation recorded}

The radial growth of the fungus on the poisoned medium was recorded at time of mycelium growth reached $90 \mathrm{~mm}$ in control. Per cent inhibition of mycelium growth of the fungus was calculated by using the formula described by Vincent (1927).

$\mathrm{I}=\frac{(\mathrm{C}-\mathrm{T})}{\mathrm{C}} \times 100$

Where,

$\mathrm{I}=$ Per cent inhibition

$\mathrm{C}=$ Radial growth in control

$\mathrm{T}=$ Radial growth in treated (fungicide/ botanicals/ bioagents).

\section{Results and Discussion}

\section{Evaluation of fungicides}

Six fungicides were assessed in vitro to find out the most effective fungicide against $A$. solani at different concentrations viz. 50, 100. 250, 500, and 1000ppm using poison food technique.

The results are presented in table 1 reveal that the significant difference among fungicides against $A$. solani was observed. Fungus growth was checked in Hexaconazole 5\% EC at 250ppm, in Trifloxystrobin $25 \% \mathrm{w} / \mathrm{w}+$ Tebuconazole $50 \% \mathrm{WG}$ at 500ppm concentration and in Thiafluzamide $24 \%$ SC at 500ppm concentration (Plate 1). Among the six fungicides, most effective fungicides was found Hexaconazole 5\% EC which exhibited 100.00 percent inhibition in mycelium growth at $100 \mathrm{ppm}$ followed by followed by Thiafluzamide 24\% SC and Trifloxystrobin $25 \% \mathrm{w} / \mathrm{w}+$ Tebuconazole $50 \% \mathrm{WG}$ at 500 ppm. However, other fungicides were unable 
to check 100.00 percent mycelium growth up to $1000 \mathrm{ppm}$ concentration (Fig. 1). The present findings are similar with the result of Singh and Singh (2006) reported that the Hexaconazole 5\% EC was very effective as it caused $100 \%$ growth inhibition of $A$. alternata. Similar type of result were also obtained by Mesta et al., (2009) who reported that the maximum inhibition of mean fungal growth of Alternaria helianthi in hexaconazole $(72.87 \%)$ followed by difenoconazole (72.61\%), mancozeb (58.29\%), chlorothalonil (51.54\%) and captan $(50.43 \%)$.

Table.1 In vitro efficacy of fungicides against Alternaria solani

\begin{tabular}{|c|c|c|c|c|c|c|}
\hline \multirow{2}{*}{ Fungicides } & \multicolumn{6}{|c|}{ Colony diameter $(\mathrm{mm})$ at different concentration } \\
\hline & 50ppm & 100ppm & 250ppm & 500ppm & 1000ppm & Mean \\
\hline $\begin{array}{l}\text { Trifloxystrobin } 25 \% \mathrm{w} / \mathrm{w} \\
+ \text { Tebuconazole } 50 \% \mathrm{WG}\end{array}$ & 26.33 & 20.67 & 13.00 & 0.00 & 0.00 & 12.00 \\
\hline Difenconazole $25 \mathrm{EC}$ & 67.00 & 64.33 & 62.00 & 61.00 & 59.00 & 62.67 \\
\hline Hexaconazole 5 EC & 12.33 & 0.00 & 0.00 & 0.00 & 0.00 & 2.47 \\
\hline Propineb $70 \mathrm{WP}$ & 65.67 & 65.00 & 62.67 & 61.33 & 55.33 & 62.00 \\
\hline Azoxystrobin $23 \% \mathrm{SC}$ & 62.67 & 60.67 & 26.33 & 13.33 & 6.33 & 33.87 \\
\hline Thiafluzamide $24 \% \mathrm{SC}$ & 13.67 & 11.33 & 7.33 & 0.00 & 0.00 & 6.47 \\
\hline Control & 89.27 & 89.27 & 89.27 & 89.27 & 89.27 & 89.27 \\
\hline \multirow[t]{2}{*}{ Mean } & 48.10 & 44.47 & 37.23 & 32.13 & 29.99 & \\
\hline & \multicolumn{2}{|c|}{$\mathrm{CV}(\%)$} & \multicolumn{2}{|c|}{ SEm \pm} & \multicolumn{2}{|c|}{ CD at $5 \%$} \\
\hline Fungicides & \multirow{3}{*}{\multicolumn{2}{|c|}{9.51}} & \multicolumn{2}{|c|}{0.94} & \multicolumn{2}{|c|}{2.65} \\
\hline Concentration & & & \multicolumn{2}{|c|}{0.79} & \multicolumn{2}{|c|}{2.24} \\
\hline $\begin{array}{l}\text { Fungicides X } \\
\text { Concentration }\end{array}$ & & & \multicolumn{2}{|c|}{2.10} & \multicolumn{2}{|c|}{5.93} \\
\hline
\end{tabular}

Table.2 In vitro efficacy of botanicals against Alternaria solani

\begin{tabular}{|c|c|c|c|c|c|c|}
\hline \multirow{2}{*}{ Botanicals } & \multicolumn{6}{|c|}{ Mycelium diameter (mm) at different concentrations } \\
\hline & $1 \%$ & $2 \%$ & $3 \%$ & $4 \%$ & $5 \%$ & Mean \\
\hline $\mathrm{P}_{1}-$ Datura stramonium & 76.00 & 74.00 & 71.00 & 71.67 & 67.67 & 72.07 \\
\hline $\mathrm{P}_{2}-$ Azadirachta indica & 70.33 & 66.33 & 63.67 & 55.33 & 52.00 & 61.53 \\
\hline $\mathrm{P}_{3}-$ Allium sativum & 60.33 & 56.00 & 52.33 & 50.67 & 49.33 & $\mathbf{5 3 . 8 7}$ \\
\hline $\mathrm{P}_{4}-$ Eucalyptus spp. & 73.67 & 66.00 & 59.67 & 57.00 & 52.33 & 61.73 \\
\hline $\mathrm{P}_{5}-$ Crotalaria juncea & 61.33 & 59.67 & 54.33 & 53.00 & 50.00 & $\mathbf{5 5 . 5 3}$ \\
\hline $\mathrm{P}_{6}-$ Euphorbia hirta & 87.33 & 86.00 & 84.67 & 83.33 & 82.00 & 84.67 \\
\hline Control & 89.93 & 89.93 & 89.93 & 89.93 & 89.93 & 89.93 \\
\hline \multirow[t]{2}{*}{ Mean } & 74.13 & 71.13 & 67.94 & 65.85 & 63.32 & \\
\hline & & $\mathrm{CV}(\%)$ & \multicolumn{2}{|c|}{ SEm \pm} & \multicolumn{2}{|c|}{ CD at $5 \%$} \\
\hline Botanicals & & 5.37 & \multicolumn{2}{|c|}{0.95} & \multicolumn{2}{|c|}{2.68} \\
\hline Concentration & & & \multicolumn{2}{|c|}{0.80} & \multicolumn{2}{|c|}{2.27} \\
\hline Botanicals X Concentration & & & \multicolumn{2}{|c|}{2.12} & \multicolumn{2}{|c|}{5.99} \\
\hline
\end{tabular}



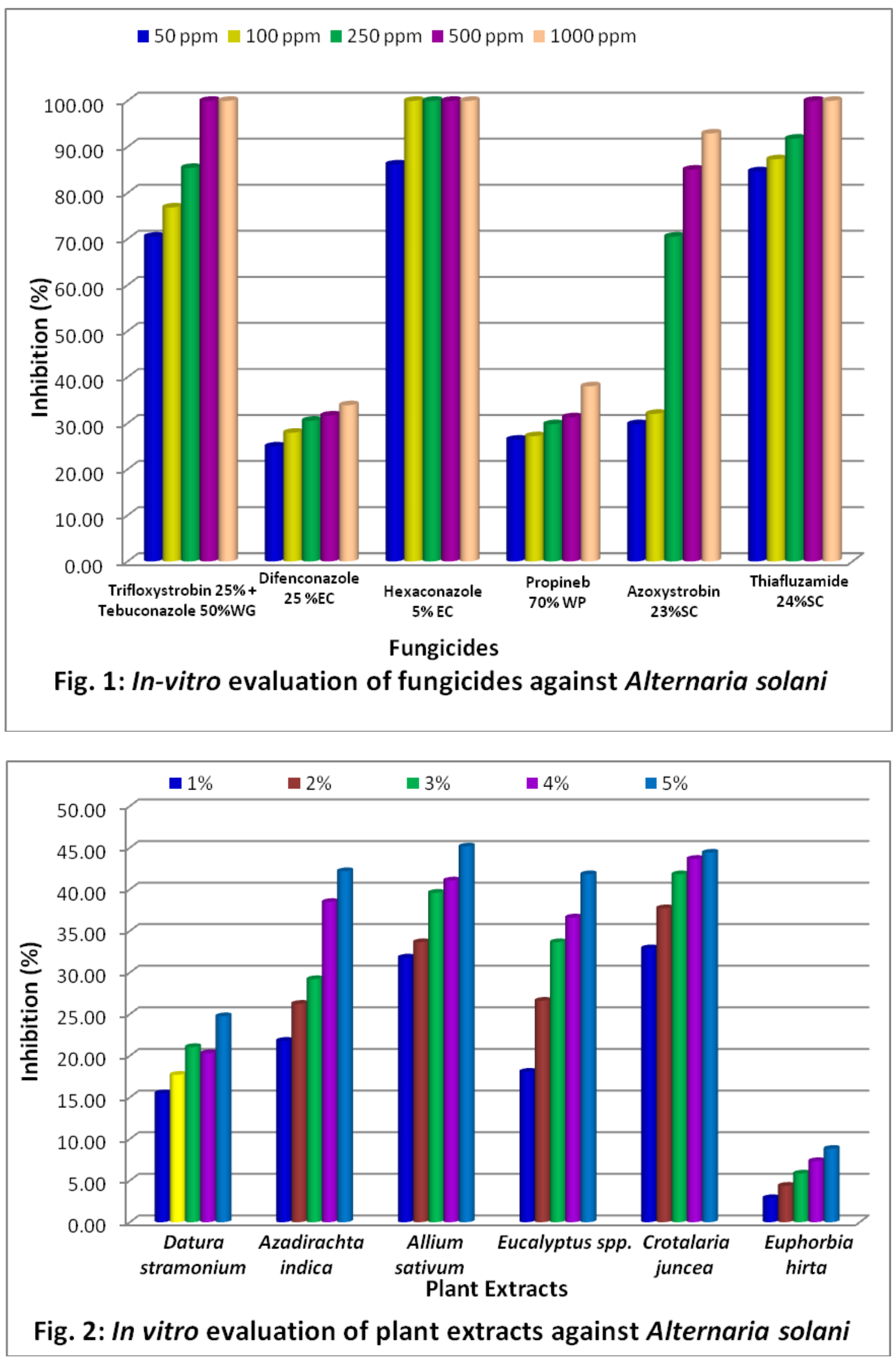
Plate.1 In vitro efficacy of fungicides against Alternaria solani

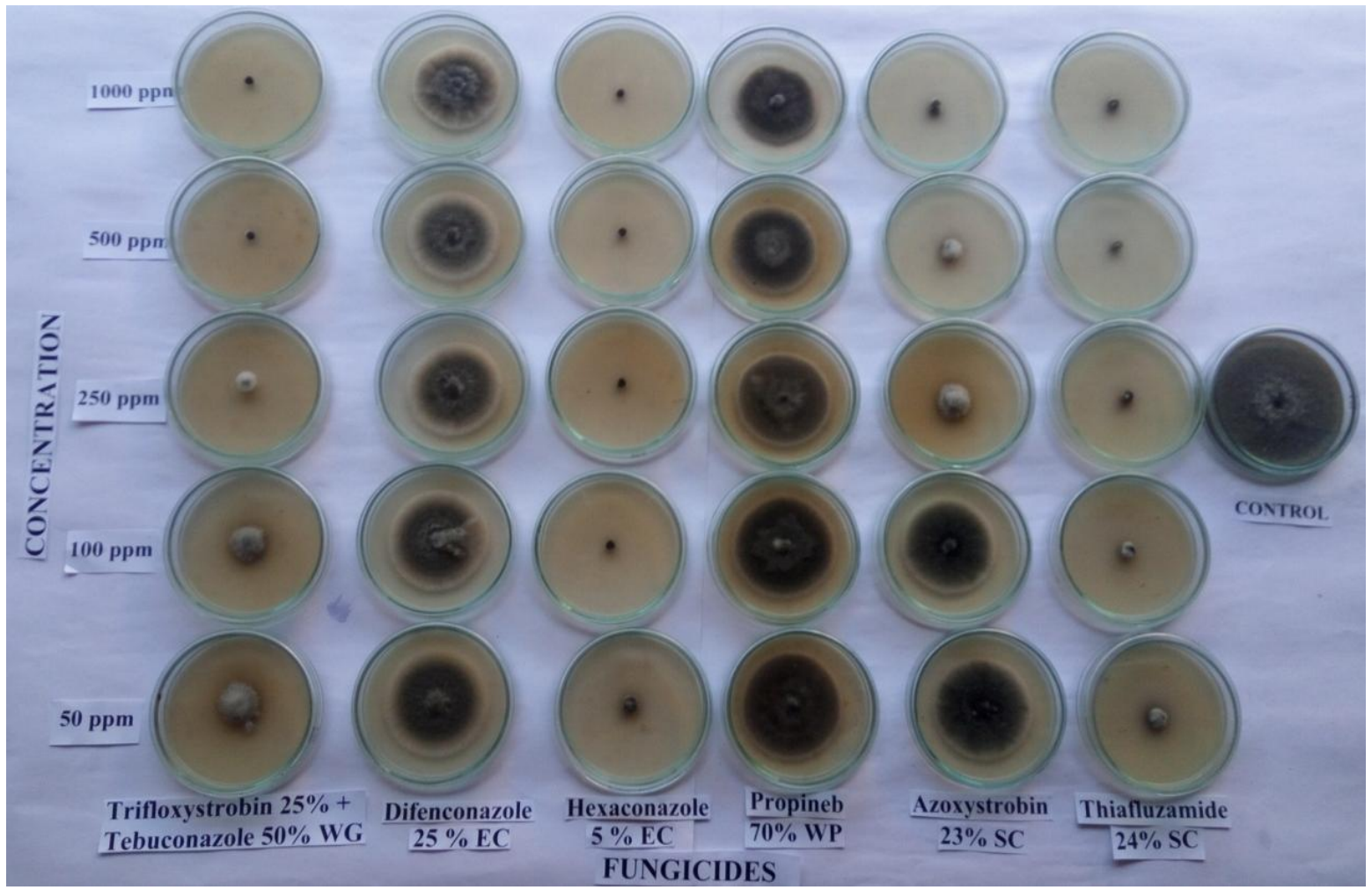

Plate.2 In vitro efficacy of plant extracts against Alternaria solani

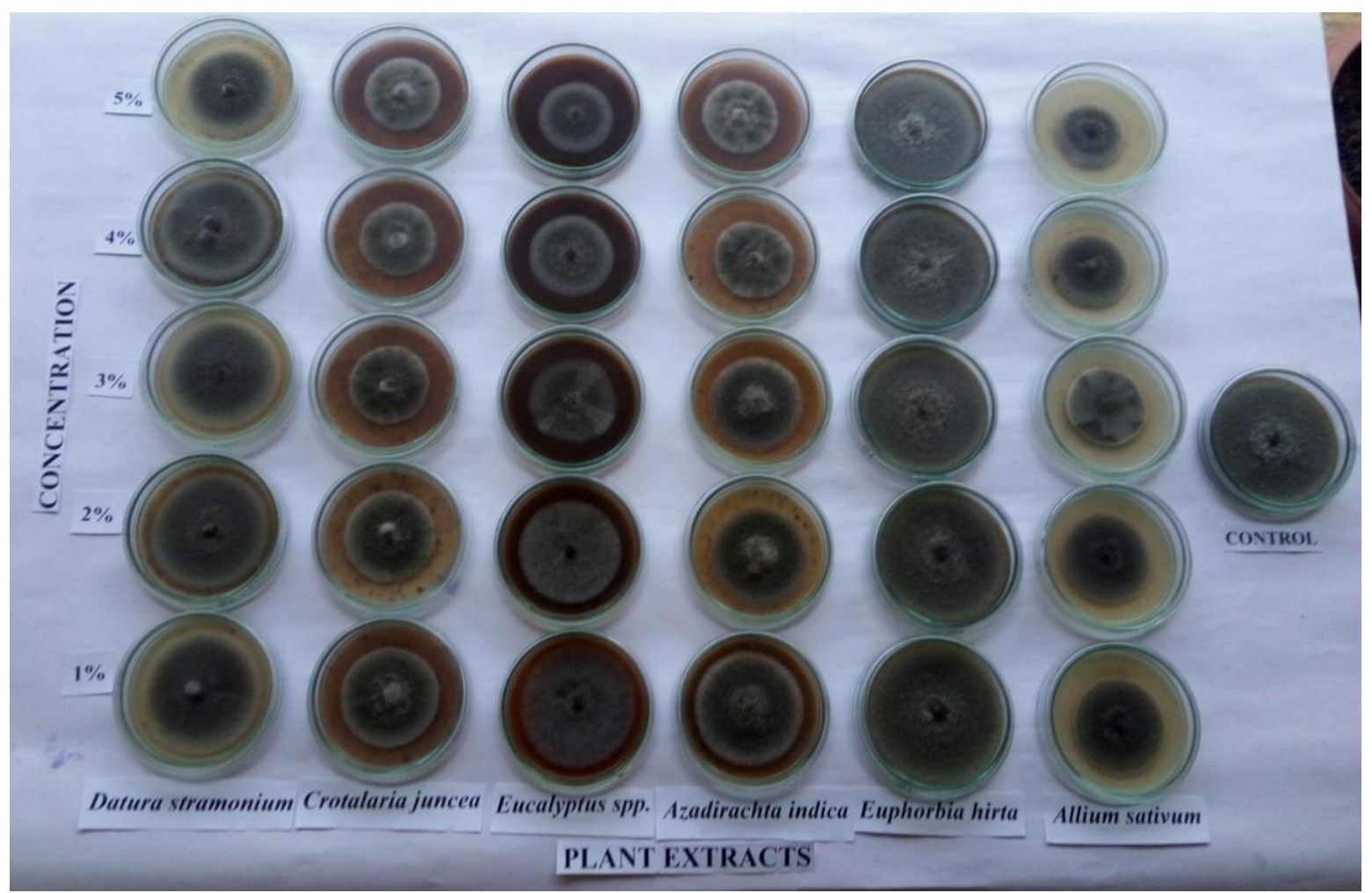




\section{Evaluation of plant extracts}

Data regarding on in vitro efficacy of plant extracts against Alternaria solani have been presented in table 2 indicated that significant difference on mycelium growth was recorded in different plant extract in at all the concentrations. Among the six plant extract tested, most effective plant extract was found Allium sativum which exhibited minimum mycelium growth $(53.87 \mathrm{~mm})$. It was significantly lower of over rest of the plant extracts. However, maximum mycelium growth $(84.67 \mathrm{~mm})$ was observed in Euphorbia hirta. In case of concentrations, minimum growth of the mycelium was observed in higher concentration (5\%) in all the plant extracts. It's indicated that the mycelium growth was reduced with gradually increased in concentration of plant extract (Plate 2). Interaction was found significant. In case of interaction between plant extract and concentration, minimum mycelium growth $(49.33 \mathrm{~mm})$ was found in Allium sativum @ 5\% which was at par with Crotalaria juncea @ 5\%(50.00mm), Allium sativum @ 4\% (50.67mm), Azadirachta indica @ 5\% $(52.00 \mathrm{~mm})$, Allium sativum @ $3 \%$ (52.33mm), Eucalyptus spp. @ 5\% (52.33mm), Crotalaria juncea @4\% (53.00 $\mathrm{mm})$, Crotalaria juncea @3\% (54.33 mm) and Azadirachta indica @ 5\% (55.33mm) and significantly lower over rest of concentrations of plant extracts. On the other hand, maximum inhibition in mycelium growth was noticed in Allium sativum @ 5\% (45.15\%) followed by Crotalaria juncea @ 5\% (44.40\%), Allium sativum @ 4\% (43.66\%), Azadirachta indica@5\% (42.18\%), Allium sativum@3\%(41.81\%),Eucalyptus spp.@ $5 \%$ (41.81), while minimum inhibition in mycelium growth of $2.89 \%$ was recorded in Euphorbia hirta@1\% (Fig. 2).

The present findings are confirmed with the results of Nashwa et al., (2012) they reported leaf extracts of $D$. stramonium, A. indica, and A. sativum@5\% inhibited highest mycelial growth of A. solani (44.4, 43.3 and $42.2 \%$, respectively). Dalpati et al., (2010) tested ten botanicals viz. Neem, Custard apple, Lantana, Eucalyptus, Marigold, Tamarind, Kanher, Garlic, Datura and Congress grass against the Alternaria macrospora causing leaf spot of cotton. The percent inhibition of botanicals ranged from 44.59 to 8.25 percent. Similar results were also reported by Sadana, and Didwania (2015) he reveal that the fresh aqueous extract of Eucalyptus obliqua @ 15\% was most effective which exhibited 88 percent inhibition of mycelial growth of $A$. solani strain A1 followed by Datura stamonium, Azadirachta indica, Calotropis procera and Polyalthia longifolia.

\section{References}

Anonymous, 2016. Horticultural statistics at a glance. Horticultural statistics Division, Department of Agriculture, Cooperation \& Farmers Welfare, Ministry of agriculture \& Farmers Welfare, Government of India. pp. 1-437.

Atherton, J.G., and J. Rudich., 1986. In: Tomato crop. Chapman and Hall, London, New York. pp. 661.

Dalpati, N.N.S., Parate, R.L. and Ingle, S.T., 2010. Efficacy of some bioagents and botanicals against Alternaria macrospora causing leaf spot of cotton. J. Plant Dis. Sci., 5(1): 95.

Johnson, A., and Booth, C., 1983. In Plant Pathologist's Pocket Book, Oxford and IBH Pub. Co. Calcutta: 136 pp.

Jones, J.B., Jones, J.P, Stall, R.E. and Zitter, T.A., 1991. Infectious antifungal. Plant Physiology, 108: 17-27.

Mathur, K., and Shekhawat, K.S., 1986. Chemical control of early blight in Kharif sown tomato. Indian Journal of Mycology Plant Pathology, 16: 235238. 
Mesta, R.K., Benagi, V.I., Shankergroud, I. and Megeri, S.N., 2009. Effect of dates of sowing and correlation of weather parameters on the incidence of Alternaria blight of sunflower. Karnataka J. Agric. Sci., 22(2): 441443.

Naik, M.K., Prasad, Y., Bhat, K.V and Rani, D., 2010. Morphological, physiological, pathogenic and molecular variability among isolates of Alternaria solani from tomato. Indian Phytopathol, 63(2): 168-173.

Nashwa S.M.A., and Abo-Elyousr K.A.M., 2012. Evaluation of various plant extracts against the early blight disease of tomato plants under greenhouse and field conditions. Plant Protect. Sci., 48: 74-79.

Nene, Y.L., and Thapliyal, P. N., 1993. Evaluation of fungicides. In: Fungicides in Plant Disease Control. Oxford and
IBH Publishing Company, New Delhi, p. 531.

Sadana, D., and Didwania, N., 2015. Bioefficacy of fungicides and plant extracts against Alternaria solani causing early blight of tomato. International Conference on Plant, Marine and Environmental Sciences (PMES-2015) Kuala Lumpur (Malaysia). Pp. 38-42.

Singh, P.C., and Singh, D., 2006. In vitro evaluation of fungicides against Alternaria alternata. Annals of Plant Protection Sciences, 14(2): 500-502.

Smith, L.J., and Kotcon, 2002. Intercropping with tomato resistant variety 'Juliet' reduces early blight on susceptible variety 'brandywine'. Phytopathology, 92: 77.

Vincent, J.M., 1927. Distortion of fungal hyphae in presence of certain inhibitors. Nature, 159: 850.

\section{How to cite this article:}

Pankaj Kumar and Singh, S. 2017. In Vitro Evaluation of Fungicides and Plant Extract against Alternaria solani (Ellis) Causing Early Blight in Tomato (Lycopersicon esculentum Mill.). Int.J.Curr.Microbiol.App.Sci. 6(9): 820-827. doi: https://doi.org/10.20546/ijcmas.2017.609.101 